\title{
BIOLOGICAL CONTROL OF PHYTOPHTHORA ROOT ROT OF AVOCADO WITH MICROORGANISMS GROWN IN ORGANIC MULCHES
}

\author{
Jefferson L. da S. Costa ${ }^{1 *}$; John A. Menge ${ }^{2}$; Willian L. Casale ${ }^{2}$ \\ ${ }^{1}$ Embrapa Arroz e Feijão, Santo Antônio de Goiás, GO, Brasil. \\ ${ }^{2}$ Department of Plant Pathology, University of California, Riverside, CA, USA
}

Submitted: October 08, 1999; Returned to authors for corrections: July 14, 2000; Approved: November 07, 2000

\begin{abstract}
Organic mulches colonized with microbial biocontrol agents, termed bioenhanced mulches, were tested for their ability to reduce Phytophthora root rot of avocado (Persea americana Mill.). Benomyl-resistant mutants of Gliocladium virens (KA 230-1) and Trichoderma harzianum (KA 159.2) isolated from suppressive soils and selected as efficient antagonists of $P$. cinnamomi were evaluated for their ability to colonize different mulches under controlled laboratory conditions. Sudangrass and a coarse yardwaste were found to be better substrates than a fine yardwaste, woodwaste or rice hulls for biocontrol agents propagules production. The most suitable conditions for colonization were an optimum temperature of $24^{\circ} \mathrm{C}$, a moisture content of $20 \%$ for sudangrass and $30 \%$ for the coarse yardwaste, and a continuous light exposure during a 15-day incubation period. In the greenhouse, fresh sudangrass and a coarse yardwaste colonized with $G$. virens and used as a surface mulch proved to be the best combination for reducing the population of $P$. cinnamomi in 4-liter pots containing artificially-infested soil. Healthy avocado roots made up $31-37 \%$ of the roots in the G. virens-mulch combinations compared to $0 \%$ healthy in infested controls after two months.
\end{abstract}

Key words: Phytophthora cinnamoni, Gliocladium virens, Trichoderma harzianum, avocado

\section{INTRODUCTION}

In California $60-75 \%$ of the avocado (Persea Americana Mill.) acreage is infested with Phitophathora cinnamomi causing an estimated annual loss of $\$ 44$ million (14). The soils used for avocado culture in California are generally very conducive to Phytophthora root rot (PRR) (44). According to Coffey (13) the absence of any mulching practice in most groves in California may also be an important factor in disease development.

Although Phytophthora cinnamomi induces severe root rot of avocados in subtropical environments, there are some locations such as in Australia, where the disease occurs but does not induce severe losses due to soil suppressiveness induced most likely by the soil microbiota $(6,7)$. The biological basis of PRR suppression in Australia has been intensively investigated, but the specific mechanisms for it are still debated.
Prior to the Australian example, only Pratt (37) and Morquer and Touvet (30), conducted any relevent assessment of antagonists to $P$. cinnamomi. Mycorrhizal Fungi were suggested as playing a role in the suppression of $P$. cinnamomi on pines and conifers $(38,41)$. Avocado roots, however, do not develop such mycorrhizal associations (14). In early studies, Trichoderma spp. were reported to be ineffective against $P$. cinnamomi (25), possibly due to their poor performance in wet soils (35). Chakraborty et al., (11) found that some species of amoebae might have the ability to perforate and lyse melanized propagules of $P$. cinnamomi.

Rhizobium isolates (29), Penicillium funiculosum (40) $P$. spinulosum (31) Myrothecium roridium (17), Epicoccum purpurescens $(=$ E. nigrum $)(8,26)$ have also been characterized as potential $P$. cinnamomi antagonists.

Developing suitable technologies for using microbial antagonists in the field requires the development of appropriate

\footnotetext{
* Corresponding author. Mailing address: EMBRAPA Arroz e Feijão, Caixa Postal 179. CEP: 75375-000, Santo Antônio de Goiás, GO, Brasil

E-mail: jcosta@cnpaf.embrapa.br.
} 
delivery technologies. In this sense the avocado system offers some opportunities, since the potting mix is fumigated or treated. Colonization of such a mix by biocontrol agents is then rendered much easier. In addition, the incorporation of a biocontrol agent growing on a suitable substrate into a planting mound or later as a mulch may be feasible $(12,20,21,22)$.

In the case of PRR of avocado, the use of organic and inorganic soil amendments has been widely reported in attempts to encourage microbial activity antagonistic to the germination and growth of $P$. cinnamomi $(36,42)$. Zentmyer (43) was the first to report reasonable control of PRR based on these principles. At that time, the great increase in microbial population with addition of alfalfa meal was considered a factor in the biological control of PRR. Zentmyer and Thompson (45) also suggested the control might be related to the fungitoxicity of the saponin fraction of alfalfa meal. However, Gilpatrick (18) later observed that control in avocado groves was not satisfactory when alfalfa meal was applied to the soil surface under trees, and some phytotoxicity was also noticed. Since many different organic soil amendments produce phytotoxic products in soil (9), the effect of such products on plant growth and disease control may be more important than most workers suspect.

The key for large-scale utilization of disease suppressive composts is the development of composts with defined and consistent properties. Technology available for some composts, such as tree barks which are largely used in greenhouse crops $(4,5)$, needs to be developed for other solid wastes. This material could potentially be incorporated into California avocado groves as a mulch and as a suitable substrate for delivering biocontrol agents.

The objectives of this research were to determine the optimum temperature, moisture content, and light necessary to colonize potential composts with fungal biocontrol agents (BCA), such as Trichoderma harzianum and Gliocladium virens and define the best mulch-BCA combination for reducing avocado PRR under greenhouse conditions.

\section{MATERIALS AND METHODS}

In a previous study, Casale (10) compared 18 different organic mulches for their ability to be colonized in vitro by some potential biocontrol agents (BCAs). Those mulches which gave the best results (rice hulls, sudan grass, wood compost, and coarse or fine yardwaste) were selected for use in this research.

Two potential biocontrol agents isolated from avocado soils at the root zone and indicating suppressiveness to PRR (10) were selected for these tests. Benomyl-resistant Gliocladium virens mutant KA230-1 and Trichoderma harzianum mutant KA159-2 were developed from these BCAs, allowing recovery from soils and mulches using a benomyl-containing medium. The assays of mulches as a substrate for growth of antagonistic microorganisms were conducted as follows. Trichoderma harzianum KA159-2 and G. virens KA230-1 were grown separately on PDA-benomyl plates for 7 days. Conidia were harvested by flooding the plates with sterile water containing $0.01 \%$ Tween 20 and dislodging with a sterile paint brush No. 14. Spore suspensions containing $1 \times 10^{6}$ conidia were used to inoculate $100 \mathrm{ml}$ fresh mulch samples (dried at $80^{\circ} \mathrm{C}$ for $24 \mathrm{hr}$ and fumigated with methyl bromide 72 hours prior to inoculation). These were placed in $33 \times 33 \mathrm{~cm}$ colorless autoclaved polyethylene bags containing a $35-\mathrm{mm}$ diameter microporus filter patch to allow air exchange.

A volume of water amended with V8c broth $(20 \%$, v/v) was added to the mulch samples to reach 10, 20,30, and $40 \%$ of moisture content (v/v). After 15 days incubation at 20, 22, 24, 28 and $32^{\circ} \mathrm{C}$, equivalents of $1.0 \mathrm{gm}$ dry weight samples were blended in $100 \mathrm{ml}$ sterile water for $10 \mathrm{sec}$., using a Betty Crocker handheld blender. Serial dilutions of $10^{-3}, 10^{-4}, 10^{-5}, 10^{-6}, 10^{-7}$, were made in 5 test tubes, plating out 5 plates each of $10^{-5}$ and $10^{-7}$ dilution for each mulch sample. Samples inoculated with Trichoderma were plated out on PDA +50 ppm benomyl +80 ppm ampicillin. Those inoculated with Gliocladium were plated out on modified Rose Bengal medium consisting of $\mathrm{K}_{2} \mathrm{HPO}_{4}$, $0.5 \mathrm{~g}$; peptone, $0.5 \mathrm{~g}$; yeast extract, $0.5 \mathrm{~g}$; dextrose, $10 \mathrm{~g}$; rose bengal, $0.05 \mathrm{~g}$; agar, $17 \mathrm{~g}$; and distilled water to make 1 liter. Streptomycin sulfate was added to the above cooled agar medium just before pouring at a concentration of $30 \mathrm{mg} / \mathrm{liter}$. Oxygall (1000 ppm) was added to both media to limit colony size and enhance colony counting accuracy. The plates were incubated in the dark. Final data was expressed in number of propagules per volume (ppv) of mulch.

After the selection of the most suitable temperature and moisture for each mulch-BCA association, the effect of light on colonization was investigated by incubating the bags for 15 days under $15 \mathrm{w}$ cool-white lamps (distant $30 \mathrm{~cm}$ ). The bags were turned over daily to homogenize inoculum production. All experimental procedures were repeated twice, and each treatment submitted to three replications. Data were analyzed by LSD and Waller-Duncan K-ratio T test, using PROC GLM of the SAS computer program (SAS Institute, Cary, NC).

\section{Inducing suppressiveness to PRR using mulches colonized with potential biocontrol agents.}

Seeds of a susceptible cultivar of avocado (Topa-Topa) were planted in plastic seedling bags containing UC mix, $\mathrm{pH}$ 5.8 , consisting of $50 \%$ fine sand, $50 \%$ peat moss plus $2.2 \mathrm{~kg}$ of dolomite, $1.5 \mathrm{~kg}$ of super phosphate, $138 \mathrm{~g}$ of $\mathrm{KNO}_{3}, 148$ $\mathrm{g} \mathrm{K}_{2} \mathrm{SO}_{4} \mathrm{~m}^{-3}$ (2). Two-month-old seedlings were then transplanted, root ball intact, into one gallon pots containing natural soil (clay loam) from Barr Ranch in Fallbrook, CA, amended with millet seed cultures of $P$. cinnamomi. Millet seeds $(300 \mathrm{~g})$ were autoclaved for $1 \mathrm{hr}$ on two consecutive days and inoculated with mycelium from two 5-day-old PDA 
cultures of $P$. cinnamomi. After 10-14 days of incubation at $24^{\circ} \mathrm{C}$, the millet cultures were blended twice $(1 \mathrm{~min}$ at high speed) in a blender and mixed into the soil $(0.1 \% \mathrm{v} / \mathrm{v})$ at the transplanting date.

The treatments, consisting of $500 \mathrm{ml}$ of different mulches colonized or not colonized with the biocontrol agents, were spread on the soil surface in each pot at the planting date. In each experiment, 6 replicates were used per treatment. Control treatments contained soil infested or not infested with $P$. cinnamomi. Pots were laid out in a randomized complete block design on benches in the greenhouse. The daily temperatures under such conditions ranged from $18.5-30^{\circ} \mathrm{C}\left(\right.$ Mean $\left.=24^{\circ} \mathrm{C}\right)$. The plants were sprinkler-type irrigated as needed. The experiments were terminated after 2 months.

The BCAs population on mulches and soil were determined at the end of each experiment by the same dilution technique described above. The P. cinnamomi populations were also determined in the soil at the same time by the dilution plate technique on cornmeal-PARPH medium selective for Phytophthora. This medium consisted of $1.8 \%$ Difco cornmeal agar (Difco Laboratories, Detroit, MI) with (per milliliter) 133 $\mathrm{mg}$ of pentachloronitro-benzene, $125 \mathrm{mg}$ of ampicillin, $10 \mathrm{mg}$ of rifampicin, $10 \mathrm{mg}$ of pimaricin, and $50 \mathrm{mg}$ of hymexazol. Sampling was conducted by collecting $10 \mathrm{~g}$ of infested soil from each experimental unit, suspending in $100 \mathrm{ml}$ sterile water, and blending with a Betty Crocker hand-held blender for $20 \mathrm{sec}$, to give $10^{-1}$ dilution. One milliliter of the soil slurry was placed on each of five plates of cornmeal-PARPH agar. After $48 \mathrm{hr}$, the soil was washed off the plates and colonies of $P$. cinnamomi, recognizable by their distinctive growth with clusters of hyphal swellings, were counted. Population densities were expressed as propagules per gram of soil.

Other data collected consisted of plant heights (measured from pot edges) at the beginning and end of each experiment, dry weight of roots, roots lengths determined by the root intersect method (34), and visual determination of percentage of root rot in comparison to the controls inoculated and noninoculated with $P$. cinnamomi. The experiments were repeated three times. All data were analyzed by Waller-Duncan K-Ratio test using PROC GLM of the PC SAS pragram (SAS Institute, Cary, NC). Proportional values were transformed to arcsin and numerical values to $\log _{10}$ before analysis.

\section{RESULTS AND DISCUSSION}

\section{Suitable conditions to bioenhance mulches with biocontrol agents}

Both biocontrol agents, Gliocladium virens (Table 1) and Trichoderma harzianum (Table 2), successfully colonized all organic composts, producing a compact mass of mycelium and

Table 1. Population of Gliocladium virens in organic mulches after 15 days as influenced by temperature and moisture.

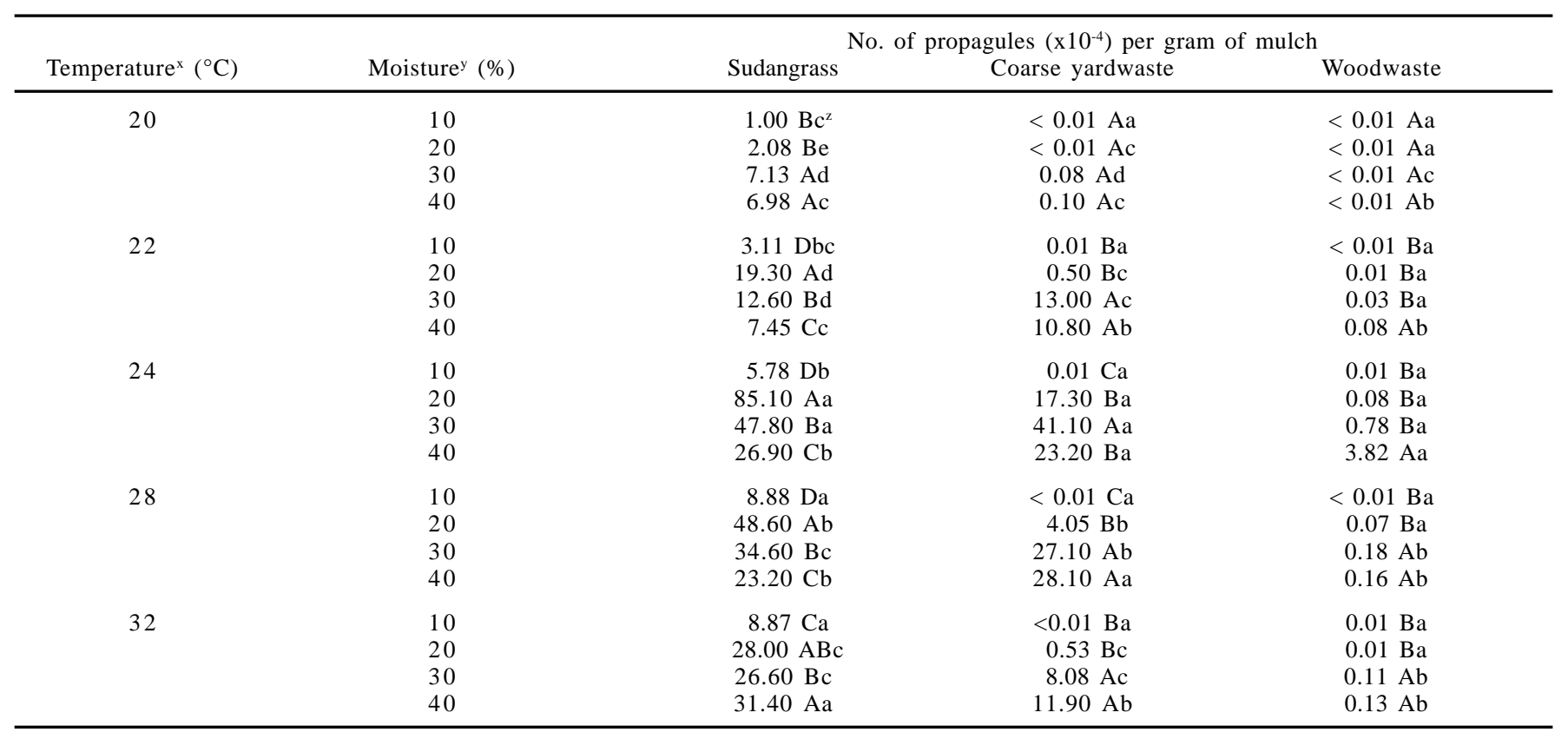

\footnotetext{
${ }^{x}$ Temperature of incubation

${ }^{y}$ Moisture content of mulches (w/w)

${ }^{2}$ Means in a column followed by upper case letters denotes significant differences between moisture tratments within each temperature and lower case denotes significant differences between temperatures each moisture tratment according to Fisher's LSD at P $<0.05$.
} 
Table 2. Population of Trichoderma harzianum in organic mulches after 15 days as influenced by temperature and moisture.

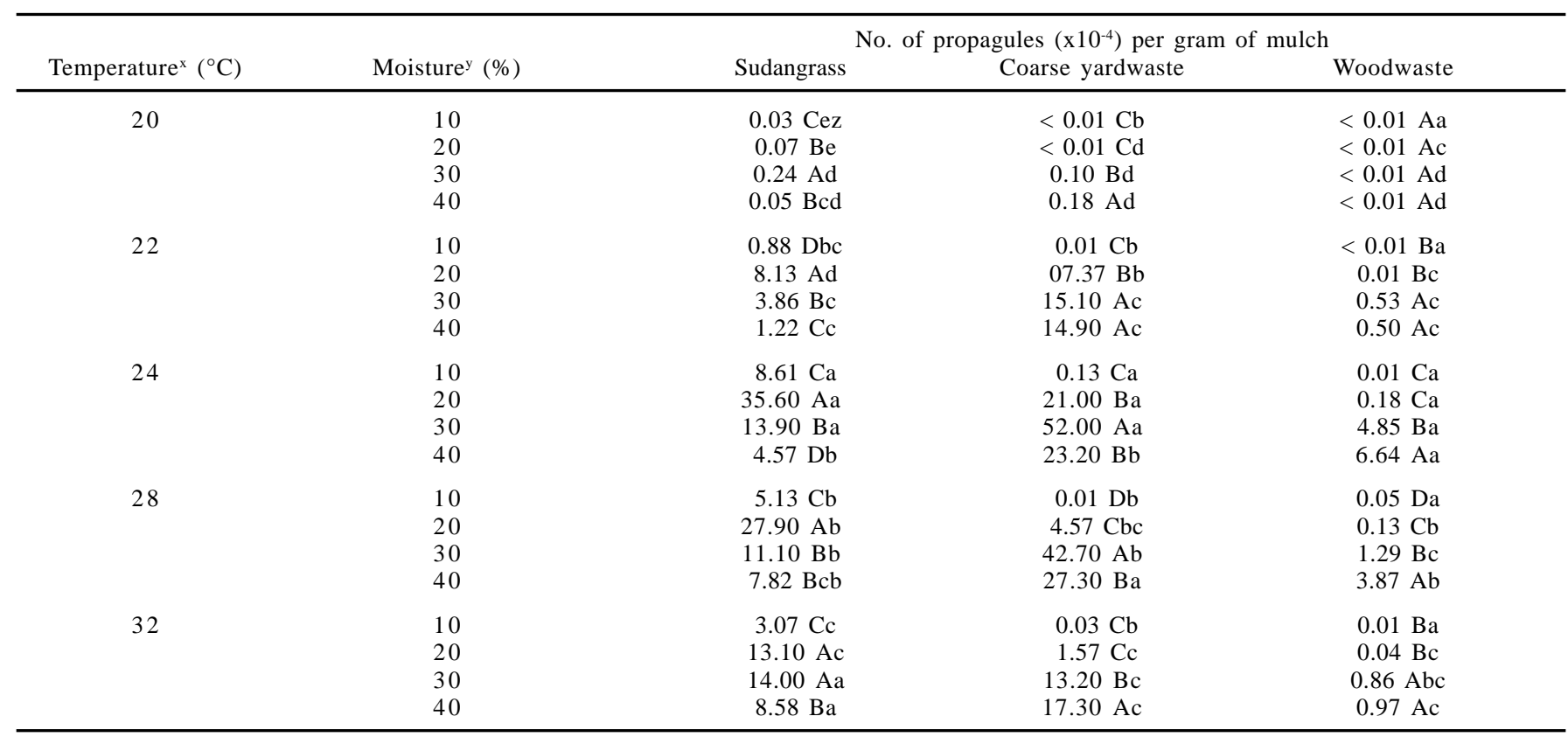

$x$ Temperature of incubation

y Moisture content of mulches (w/w)

${ }^{2}$ Means in a column followed by upper case letters denotes significant differences between moisture tratments within each temperature and lower case denotes significant differences between temperatures each moisture tratment according to Fisher's LSD at P $<0.05$.

a slight conidiation. However the efficiency varied among composts and temperature-moisture combinations, presenting a wide range of propagules per volume of mulch (ppv) (Tables 1 and 2).

The less favorable mulches for colonization with G. virens were the fine yardwaste and the rice hulls, since they didn't produce more than $5 \mathrm{ppv}$ and no statistical difference could be detected at the various temperature-moisture combinations. The wood compost was a slightly better substrate, with a temperature of $24^{\circ} \mathrm{C}$ and $40 \%$ moisture content as most conducive for colonization. Sudan grass and the coarse yard waste compost were by far the best substrates for G. virens colonization. Both gave best results at $24^{\circ} \mathrm{C}$, but sudan grass was better colonized at $20 \%(\mathrm{v} / \mathrm{v})$ moisture content and coarse yardwaste at $30 \%(\mathrm{v} /$ v) moisture content. Under such conditions these composts could produce, respectively, 8,500 and 4,100 ppv, indicating the superiority of sudan grass over coarse yardwaste (Table 1).

On the other hand, T. harzianum colonized better the coarse yardwaste $(5,200 \mathrm{ppv})$ than sudan grass $(3,500 \mathrm{ppv})$. The most suitable conditions for T. harzianum to colonize coarse yardwaste were at either $24^{\circ} \mathrm{C}$ or $28^{\circ} \mathrm{C}$ when the mulch moisture content was maintained at $30 \%(\mathrm{v} / \mathrm{v})$. Sudan grass was better colonized at $24^{\circ} \mathrm{C}$, with $20 \%$ moisture content (Table 1). The optimum conditions for colonization of sudan grass with T. harzianum and G. virens were the same; however, the latter was able to produce almost 2.5 as much inoculum than the former. Trichoderma harzianum, when using wood compost as a substrate, was able to consistently produce higher amounts of inoculum with $40 \%$ of moisture content and $24^{\circ} \mathrm{C}$ incubation. (Tables 1 and 2) In this study, whenever the ideal moisture content for each mulch was achieved, any additional increase in moisture level tended to reduce production of ppv, the mycelia were, in general, less compact, and the visual conidiation (greenish color of fungi growth) was reduced. In previous studies, Trichoderma spp. have not been recorded as effective against $P$. cinnamomi (25), due to their reputed poor performance in soils with high moisture content (35).

The temperature played a minor effect on inoculum production. Sometimes, in this study an ideal single temperature for mulch colonization could not be determined. High amounts of inoculum of both BCAs were produced either at 24 or $28^{\circ} \mathrm{C}$ as shown with coarse yardwaste (Table 2).

It has been known for years that fresh organic matter can serve as a direct food base to fungi $(16,24)$. However, there is a lack of reports in the literature regarding on the use of organic matter as an artificial substrate to enhance the inoculum potential of BCAs for use against P. cinnamomi. Apparently, the association of organic composts with BCAs to control a plant disease have found in the Rhizoctonia solani a better 
research model (32). Hyperparasitic activity of Trichoderma against $R$. solani eradicates the pathogen in mature compost. In fresh compost, on the other hand, the pathogen survives in spite of the higher Trichoderma population (33). The Trichoderma strain is largely active as a saprophyte in fresh organic matter. Cellulose concentration and compost stability, therefore, regulate the hyperparasitic activity of biocontrol agents such as Trichoderma spp. $(24,15)$ suggested that the mechanism could involve repression of chitinase activity in fresh compost high in cellulose.

In the present study only fresh composts were used and, since both G. virens and T. harzianum have the ability to colonize cellulolytic material (35), that may be considered an important factor for colonization of mulches that contain higher content of cellulose like sudan grass.

Most species of Trichoderma and Gliocladium are photosensitive sporulating readily with more conidia being produced during the light period $(3,35)$. In this research the effect of light on the bioenhancement of mulches with BCAs was significant only for sudan grass and the coarse yardwaste. The production of ppv of G. virens and T. harzianum was increased by about $20 \%$ due to the phialoconidiogenesis induced by the continued exposure to light. Conidiogenesis was observed mostly at the mulch/incubation plastic bag interface; the inner 'ball' of mulches tended to produce a dense mycelia, especially in mulches that tend to clump together like sudan grass. The usefulness of light for the enhancement of $G$. virens and $T$. harzianum inoculum potential through conidiogenesis has been discussed. A relationship seems to exist between the kind or size of the propagules of these organisms and their sensitivity to soil fungistasis; conidia are expected to be more sensitive than hyphae or chlamydospores $(28,35 ; 39,27)$ showed that Gliocladium, Trichoderma and other potential biocontrol fungi proliferate abundantly in various natural soils when added as young mycelium in intimate contact with a food base, but not as conidia with or without a food base. For this reason, in the subsequent greenhouse studies, the mulches were all incubated under dark conditions, since the amount of inoculum produced was already maximized into acceptable levels for deliver into the soil.

\section{Suppressiveness to PRR using mulches colonized with potential biocontrol agents.}

The potential of G. virens and T. harzianum as biocontrol agents to suppress $P$. cinnamomi when delivered by organic mulches were evaluated in a number of two-month-period greenhouse experiments. The initial inoculum level of $P$. cinnamomi in the inoculated soil ranged from 24 to $30 \mathrm{ppg}$, while the non-inoculated control had a natural infestation of 0 5 ppg. None of the treatments in this research was able to reduce the initial population of the pathogen. However, some mulch-BCA combinations were able to reduce the final population (110-126 ppg) by more than 50\%. In a two-monthperiod experiment, $P$. cinnamomi increased 3-4 fold its initial population into the soil. During the same period, sudan grass and a coarse yardwaste efficiently delivered the BCAs in the soil to the point that consistent populations of $G$. virens $(1,200$ $1,500 \mathrm{ppg}$ ) and T. harzianum (1000-1080 ppg) were established. Because with this system the final population of $P$. cinnamomi increased in only 0.5-1 fold, we assume that these organisms were antagonizing the pathogen. The antagonism was also reflected on the root health index. Using sudan grass and coarse yardwaste, G. virens treatments improved root health by 31 37\% (Table 3 and Fig. 1), while T. harzianum improved root health $22-25 \%$ (Table 4). The efficacy of these organisms as biocontrol agents suggests that they were able to colonize the rhizoplane of avocado roots. The strong cellulolytic activity of these fungi $(1,35)$, which probably played a strong role colonizing the mulches, might also be acting to favor their competitiveness in soil and result in their ability to colonize the rhizosphere of Persea americana. In so doing, they might antagonize the pathogen before it can damage the new feeder roots, resulting in a increase in root health over the inoculated control plants.

A two-months experiment cannot, however, detect wether the BCAs would be able to continuously proliferate in the plant rhizoplane. Further studies are necessary since the lack of proper nutrients, the presence of toxic substances in root exudation, or the presence of antagonistic or competing organisms may eventually be an obstacle for massive augmentation in the soil $(6,23,35)$.

Overall in this study, wood compost was not a promising substrate for delivering the biocontrol agents. Consequently it will not be used in further studies. These results indicate the effectiveness of sudan grass and coarse yardwaste in delivering G. virens or T. harzianum. However the general data did not significantly differentiate sudan grass from coarse yardwaste, except that coarse yardwaste was able to support the BCAs longer than sudan grass. By the end of two months, 410-480 ppv of BCAs could still be recovered from he coarse yardwaste, while only 80-130 ppv were recovered from sudan grass (Tables 3 and 4). These results suggest that for the control of a longterm disease like PRR, extended periods of delivery of the BCAs might be more successful.

Among the other independent variables observed in the greenhouse studies, root dry weight and root length were useful only in the $G$. virens experiments for differentiating between treatments with or without the BCA. However no statistical differences were detected among the types of mulch (Table 3 ). Also no differences were detected in root dry weight or root length (34) among treatments containing the organic mulches alone or associated with $T$. harzianum (Table 4). The lack of differences with these parameters, and also with plant height (data not presented), may be attributed to the short length of 
the experiments associated the high genetic heterogeneity of Topa Topa seedlings used in the study. Seedlings with higher genetic homogeneity (clones) in longer term experiments might result in more control of these extraneous variables.

The use of fresh organic composts as an effective and economic food base for introducing specific biocontrol agents into avocado system to suppress PRR has been shown before (17). However the technique for mixing the colonized substrate into the soil, can be achieved only at the initial planting mound. Once the avocado grove is established, the substrate cannot be continuously mixed into the soil. The new avocado feeder roots that are continuously produced concentrate at the top $10-\mathrm{cm}$ layer of the soil, and any manipulation in soil structure can damage the roots, thereby stressing the plants, and sometimes causing death (19). As mentioned elsewhere, because PRR of avocado is a typical long-term disease problem, long-term strategies for delivering the potential biocontrol agents have to be developed. Drenching the soil with conidial suspensions or mycelial preparations has proved to be not effective for controlling PRR (17) and many other diseases (35).

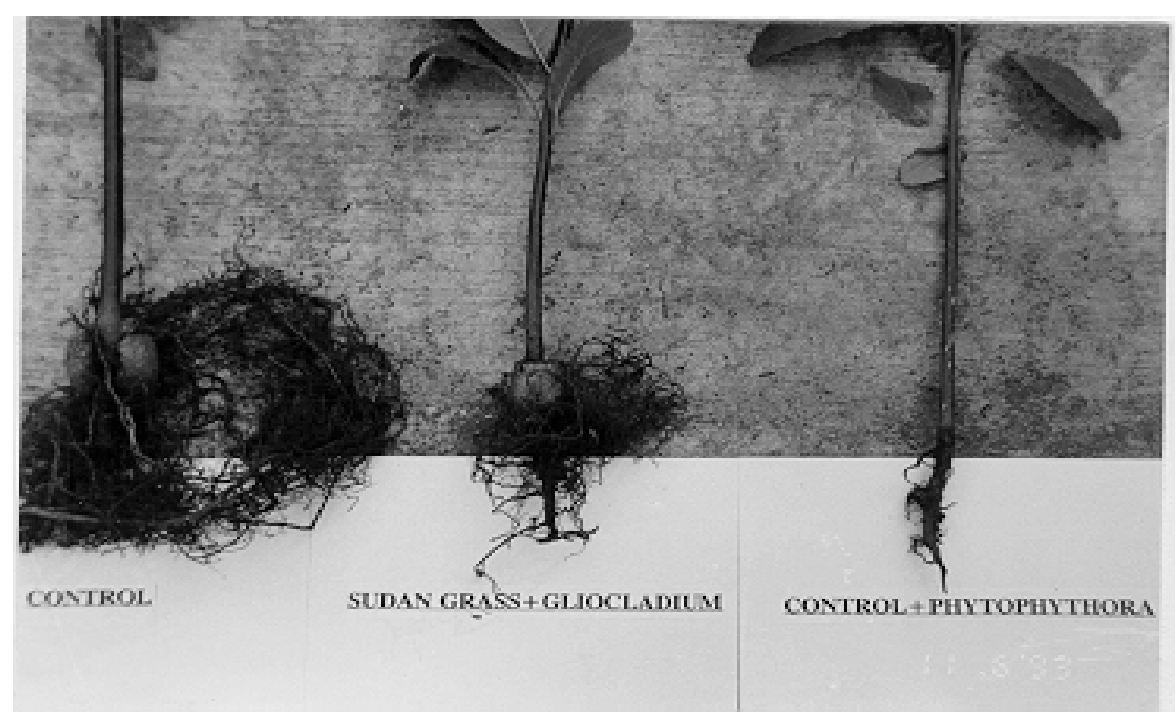

Figure 1. Sudan Grass associated with Gliocladium virens can improve root health and the root length of avocado under greenhouse condition.

Table 3. Effect of mulches and Gliocladium virens on the control of Phytophthora root rot of avocado in a 2- month greenhouse experiment.

\begin{tabular}{lcccccc}
\hline Treatments & $\begin{array}{c}\text { \% of } \\
\text { healthy } \\
\text { roots }\end{array}$ & $\begin{array}{c}\text { Root dry } \\
\text { weight } \\
(\mathrm{gm})\end{array}$ & $\begin{array}{c}\text { Root } \\
\text { length } \\
(\mathrm{cm})\end{array}$ & $\begin{array}{c}\text { P. cinnamomi } \\
\text { in the } \\
\text { soil }(\mathrm{ppg})^{\mathrm{x}}\end{array}$ & $\begin{array}{c}\text { G. virens } \\
\text { in the } \\
\text { soil }(\mathrm{ppg})\end{array}$ & $\begin{array}{c}\text { G. virens } \\
\text { in the } \\
\text { mulches }(\mathrm{ppg})\end{array}$ \\
\hline Non infested control & $100.0 \mathrm{~A}^{\mathrm{y}}$ & $13.6 \mathrm{~A}$ & $459.2 \mathrm{~A}$ & $2 \mathrm{C}$ & $0 \mathrm{D}$ & - \\
Sudangrass + G. virens & $37.9 \mathrm{~B}$ & $6.9 \mathrm{~B}$ & $108.2 \mathrm{BC}$ & $69 \mathrm{~B}$ & $1450 \mathrm{~A}$ & $140 \mathrm{~B}$ \\
Coarse yardwaste + G. virens & $31.7 \mathrm{~B}$ & $6.3 \mathrm{~B}$ & $115.1 \mathrm{~B}$ & $66 \mathrm{~B}$ & $1190 \mathrm{~B}$ & $410 \mathrm{~A}$ \\
Woodwaste + G. virens & $19.1 \mathrm{BC}$ & $5.9 \mathrm{BC}$ & $96.2 \mathrm{BC}$ & $87 \mathrm{AB}$ & $72 \mathrm{C}$ & $38 \mathrm{C}$ \\
Sudangrass & $7.9 \mathrm{C}$ & $5.4 \mathrm{C}$ & $71.1 \mathrm{CD}$ & $90 \mathrm{AB}$ & $0 \mathrm{D}$ & $0 \mathrm{C}$ \\
Coarse yardwaste & $8.3 \mathrm{C}$ & $5.3 \mathrm{C}$ & $75.7 \mathrm{CD}$ & $93 \mathrm{~A}$ & $0 \mathrm{D}$ & $0 \mathrm{C}$ \\
Woodwaste & $6.2 \mathrm{C}$ & $4.0 \mathrm{C}$ & $77.3 \mathrm{BC}$ & $101 \mathrm{~A}$ & $0 \mathrm{D}$ & $0 \mathrm{C}$ \\
Infested control & $0.0 \mathrm{C}$ & $4.1 \mathrm{C}$ & $59.2 \mathrm{D}$ & $113 \mathrm{~A}$ & $0 \mathrm{D}$ & -- \\
\hline
\end{tabular}

$\mathrm{x}$ ppg = propagules per gram.

y Means within a column followed by the same letter are not significantly different at $\mathrm{P}=0.05$ according to Waller-Duncan's k-ttest. 
Table 4. Effect of mulches and Trichoderma harzianum on the control of Phytophthora root rot of avocado in a 2-month greenhouse experiment.

\begin{tabular}{lcccccc}
\hline Treatments & $\begin{array}{c}\% \text { of } \\
\text { healthy } \\
\text { roots }\end{array}$ & $\begin{array}{c}\text { Root dry } \\
\text { weight } \\
(\mathrm{gm})\end{array}$ & $\begin{array}{c}\text { Root } \\
\text { length } \\
(\mathrm{cm})\end{array}$ & $\begin{array}{c}\text { P. cinnamomi } \\
\text { in the } \\
\text { soil }(\mathrm{ppg})^{\mathrm{x}}\end{array}$ & $\begin{array}{c}\text { G. virens } \\
\text { in the } \\
\text { soil (ppg) }\end{array}$ & $\begin{array}{c}\text { G. virens } \\
\text { in the } \\
\text { mulches (ppg) }\end{array}$ \\
\hline Non infested control & $100.0 \mathrm{Az}$ & $11.7 \mathrm{~A}$ & $571.0 \mathrm{~A}$ & $6 \mathrm{E}$ & $0 \mathrm{C}$ & - \\
Sudangrass + G. virens & $25.8 \mathrm{~B}$ & $6.8 \mathrm{~B}$ & $8.2 \mathrm{BC}$ & $83 \mathrm{D}$ & $1030 \mathrm{~A}$ & $80 \mathrm{~B}$ \\
Coarse yardwaste + G. virens & $22.9 \mathrm{~B}$ & $5.7 \mathrm{BC}$ & $84.6 \mathrm{~B}$ & $86 \mathrm{D}$ & $890 \mathrm{~A}$ & $480 \mathrm{~A}$ \\
Woodwaste + G. virens & $10.8 \mathrm{C}$ & $5.5 \mathrm{BC}$ & $71.8 \mathrm{BC}$ & $102 \mathrm{C}$ & $120 \mathrm{~B}$ & $92 \mathrm{~B}$ \\
Sudangrass & $9.2 \mathrm{CD}$ & $4.5 \mathrm{CD}$ & $58.8 \mathrm{BC}$ & $106 \mathrm{BC}$ & $0 \mathrm{~A}$ & $0 \mathrm{C}$ \\
Coarse yardwaste & $7.3 \mathrm{CD}$ & $4.8 \mathrm{CD}$ & $60.2 \mathrm{BC}$ & $115 \mathrm{AB}$ & $0 \mathrm{C}$ & $0 \mathrm{C}$ \\
Woodwaste & $8.6 \mathrm{CD}$ & $4.2 \mathrm{D}$ & $51.2 \mathrm{C}$ & $114 \mathrm{AB}$ & $0 \mathrm{C}$ & $0 \mathrm{C}$ \\
Infested control & $0.0 \mathrm{C}$ & $3.1 \mathrm{D}$ & $43.6 \mathrm{C}$ & $126 \mathrm{~A}$ & $0 \mathrm{C}$ & -- \\
\hline
\end{tabular}

${ }^{\mathrm{x}} \mathrm{ppg}=$ propagules per gram.

${ }^{y}$ Means within a column followed by the same letter are not significantly different at $\mathrm{P}=0.05$ according to Waller-Duncan's k-ttest.

The results in this work suggest that appropriate organic mulches can be efficiently colonized by some biocontrol agents, and also that at least for a short period the mulches could be used to deliver BCAs into soils. Future research is encouraged to confirm the role of bioenhanced mulches as an appropriate measure for the control of Phytophthora root rot in avocados and determine which possible mechanisms of suppressiveness are involved.

\section{RESUMO}

\section{Controle biológico da podridão radicular de Phytophthora no abacateiro utilizando substratos orgânicos colonizados}

Compostos orgânicos colonizados com agentes de controle microbiológico, então denominados compostos bioativados, foram testados quanto a sua habilidadade controlar à podridão radicular de Phytophtora no abacateiro (Persea americana Mill.) Mutantes de Gliocladium virens (KA 230-1) e Trichoderma harzianun (KA 159-2) resistentes a benomyl recuperados de solos supressivos e selecionados como eficientes antagonistas à $P$. cinnamoni foram avaliados quanto à sua capacidade de colonizar diversos compostos orgânicos em condições de laboratório. O Capim Sudão e um Composto de Jardim de alta granulação demonstraram quanto à sua capacidade de multiplicar propágulos de agentes de biocontrole, serem superiores à um composto de Jardim de granulação fina, à um composto de madeira e à um composto de casca de arroz. A condição ideal de colonização destes compostos foi encontrada à $24^{\circ} \mathrm{C}$ sob teor de umidade de $20 \%$ para Capim Sudão e $30 \%$ para o composto de Jardim de alta granulação, desde que incubados por 15 dias. Em casa de vegetação Capim
Sudão e o Composto de Jardim de alta granulação quando colonizados por G. virens e utilizados como cobertura superficial do solo demonstraram serem as melhores combinações para redução da população de $P$. cinnamomi. Em vasos contendo solos artificialmente infestados e cultivados com abacateiro por dois meses, a combinação destes compostos com G. virens produziu de 31 à $37 \%$ de raízes de abacateiro sadias contra $0 \%$ de sanidade no controle.

Palavras-chave: Phytophthora cinnamoni, Gliocladium virens, Trichoderma harzianum, abacateiro

\section{REFERENCES}

1. Ahmad, J. S.; Baker, B. Competitive saprophytic ability and cllulolytic activity of rhizosphere-competent mutants of Trichoderma harzianum. Phytopathology. 77:182-189, 1987.

2. Baker, K. F., ed. The U. C. System for Producing Healthy ContainerGrown Plants. University of California, Division of Agricultural Sciences. Agricultural Experiment Station Extension Service., 1957, $332 \mathrm{pp}$.

3. Bartnicki-Garcia, S. Cell wall chemistry, morphogenesis, and taxonomy of fungi. Ann. Rev. Microbiol. 22:87-108, 1968.

4. Borst, G. Soil is said to influence biological control efforts. AvocadoGrower (Vista, Calif.), 1983a., v.7, p34-35.

5. Borst, G. Organic matter helps control root rot spread. AvocadoGrower (Vista, CA), 1983b, v.7, p38-39.

6. Broadbent, P.; Baker, K. F. Behavior of Phytophthora cinnamomi in soils suppressive and conducive to root rot. Aust. J. Agric. Res. 25:121137, 1974a

7. Broadbent, P.; Baker, K. F. Association of bacteria with the sporangium formation and breakdown of sporangia in Phytophthora spp. Aust. J. Agric. Res. 25:139-145, 1974b.

8. Brown, A. E.; Finlay, R.; Ward, J. S. Anti fungal compounds produced by Epicoccum purpurascens against soil-borne plant pathogenic fungi. Soil Biol. Biochem. 19:657-664, 1987.

9. Carley, H. E.; Watson, R. D. Plant phytotoxins as possible predisposing agents to root rots. Phytopathology. 57:401-404, 1967. 
10. Casale, W. L. Analysis of suppressive soils and development of biological control methods for Phytophthora root rot of avocado. California Avocado Society Year Book. Saticoy, CA, 1990, v.74, pp.53.

11. Chakraborty, S.; Old, K. M.; Warcup, J. H. Amoebae from a take-all suppressive soil which feed on Gaeumannomyces graminis tritici and other soil fungi. Soil Biol. Biochem.15:17-24, 1983.

12. Chen, W.; Hoitink, H. A. J.; Madden, L.V. Microbial activity and biomass in container media for predicting suppressiveness to dampingoff caused by Pythium_ultimum . Phytopathology, 78:1447-1450, $1988 \mathrm{a}$

13. Coffey, M. D. Phytophthora root rot of avocado: an integrated approach to control in California. Plant Dis. 71:1046-1052, 1987.

14. Coffey, M. D. Phytophthora root rot of avocado. Pages 423-444. In: Plant Diseases of International Importance. I. Kumar, H. D. Chaube, V. S. Singh, and A. N. Mukhopadhyav. CRC Press, 1992, 456 pp.

15. Elad, Y.; Chet. I., Henis, Y. Degradation of plant pathogenic fungi by Trichoderma harzianum. Can. J. Microbiol. 28:719-725, 1982.

16. Garrett, S. D. Decomposition of cellulose in soil by Rhizoctonia solani Kuhn. Trans. Br. Mycol. Soc..45:114-120, 1962.

17. Gees, R.; Coffey, M. D. Evaluation of a strain of Myrothecium roridium as a potential biocontrol agent against Phytophthora cinnamomi. Phytopathology. 79:1079-1084, 1989.

18. Gilpatrick, J. D. Role of ammonia in the control of avocado root rot with alfalfa meal soil amendment. Phytopathology. 59:973-978, 1969a.

19. Gilpatrick, J. D. Effect of soil amendments upon inoculum survival and function in Phytophthora root rot of avocado. Phytopathology. 59:979-985, 1969b.

20. Hardy, G. E. St. J.; Sivasithamparam, K. Effects of sterile and nonsterile seachated extracted from composted eucalyptus bark and pinebark container media on Phytophthora spp. Soil Biol. Biochem..23:2530, 1991a.

21. Hardy, G. E. St. J.; Sivasithamparam, K. How container media and matric potential affect the production of sporangia, oospores and chlamydospores by three Phytophthora species. Soil Biol. Biochem. 23:31-39, 1991b.

22. Hardy, G. E. St. J.; Sivasithamparam, K. Sporangial responses do not reflect microbial suppression of Phytophthora drechsleri in composted eucalyptus bark mix. Soil Biol. Biochem. 23:757-765, 1991c.

23. Hoitink, H. A. J.; Fahy, P. C. Basis for the control of soilborne pathogens with composts. Ann. Rev. Phytopathol. 24:93-114, 1986.

24. Hoitink, H. A. J.; Boehm, M. J.; Hadar, Y. Mechanisms of suppression of soilborne plant pathogens in compost amended substrates. Page 601-621 In: Science and Engineering of composting: Design, Environmental, Microbiological and Utilization Aspects. H. A. J. Hoitink and H. M. Keener Eds. Ohio St. Univ., 1993, 728 pp.

25. Kelley, W. D. Evaluation of Trichoderma harzianum-impregnated clay granules damping-off of pine seedlings. Phytopathology. 1976, v.66, pp. 1023.

26. Kovacikova, E.; Kudela, V. Antagonistic interactions between pathogenic and saprophytic fungi isolated from plant roots. Symbiosis (Rehovot). 9:355-361, 1990 .
27. Lewis, J. A.; Papavizas, G. C. A new approach to stimulate population proliferation of Trychoderma species and other potential biocontrol fungi introduced into natural soils. Phytopathology. 74:1240-1244, 1984.

28. Lockwood, J. L. Fungistasis in soils. Biol. Rev. 52:1-43. 1977.

29. Malajczuk, N.; Pearce, M.; Litchfield, R. T. Interactions between Phytophthora cinnamomi and Rhizobium isolates. Trans. Br. Mycol. Soc. 82:491-500, 1984

30. Morquer, R.; Touvet, A. Comparison between biological control and chemo-therapy against root parasites of arborescent species in climatic conditions. C. R. Acad. Sci. Paris Serie. D. 274:234-239, 1972.

31. Murray, D. I. C. Rhizosphere microorganisms from the jarrah forests and their effects on vegetative growth and sporulation in Phytophthora cinnamomi Rands. Aust. J. Bot. 35:567-580, 1987.

32. Nelson, E. B.; Hoitink, H. A. J. The role of microorganisms in the suppression of Rhizoctonia solani in container media amended with composted hardwood bark. Phytopathology. 73:274-278, 1983.

33. Nelson, E. B.; Kuter, G. A.; Hoitink, H. A. J. Effect of fungi antagonists and compost age on suppression of Rhizoctonia damping-off in container media amended with composted hardwood bark. Phytopathology. 73:1457-1462, 1983.

34. Newman, E. I. A method of estimating the total length of root in a sample. J. Appl. Ecol. 5:739-45, 1966.

35. Papavizas, G. C. Trichoderma and Gliocladium: biology, ecology, and potential for biocontrol. Ann. Rev. Phytopathol. 23:23-54, 1985.

36. Pegg, K. G.; Whiley, A. W. Phytophthora control in Australia. Year book, South African Avocado Growers' Association, 1987, n.10, p.9496.

37. Pratt, B. H. Isolation of basidiomycetes from Australian eucalypt forest and assessment of their antagonism to Phytophthora cinnamomi. Brit. Mycol. Soc. Trans. 56:243-250, 1971.

38. Schild, D. E.; Kennedy, A.; Stuart, M. R. Isolation of symbiont and associated fungi from ecotomycorrhizas of Sitka. European J. Forest Pathol. 18:51-61, 1988.

39. Schippers, B.; Meijer, J. M.; Liem, J. I. Effect of ammonia and other soil volatiles on germination and growth of soil fungi. Trans. Br. Mycol. Soc. 79:253-259, 1982.

40. Tsao, P. H.; Fang, J. G.; Krausman, E.; Alizaden, A. Biological control of Phytophthora root rots by use of Penicillium funiculosum. In: XII International Plant Protection Congress. Rio de Janeiro. Brazil. August 1991.n. pp. 1991.

41. Vrot, F.; Grente, J. Research for a method of biological control of ink disease by using mycorrhizal symbiosis. European J. Forest Pathol. 15:379-383, 1985 .

42. Whiley, A. W.; Sarana, H. J. B.; Culil, B. W.; Pegg, K. G. Manage avocado tree growth cycles for productivity gains. Queens land Agric. J. Jan-Feb.:29-36, 1992.

43. Zentmyer, G. A. Biological control of Phytophthora root rot of avocado with alfalfa meal. Phytopathology. 53:1383-1387, 1963.

44. Zentmyer, G. A. Avocado diseases. Tropical Pest Management n.30, 1984, p.388-400.

45. Zentmyer, G. A.; Thompson, C. R. The effect of saponins from alfalfa on Phytophthora cinnamomi in relation to control of root rot of avocado. Phytopathology. 57:1278-1279, 1967. 